\title{
Characteristics of Nitisol profiles as affected by land use type and slope class in some Ethiopian highlands
}

\author{
Eyasu Elias ${ }^{*}$
}

\begin{abstract}
Background: The success of soil management depends on understanding of how soils respond to agricultural land use practices over time. Nitisols are among the most extensive agricultural soils in the Ethiopian highlands but soil degradation threatens their productive capacity. In this study, the effects of two land use systems, intensive cereal and agroforestry systems, and slope class on physical and chemical characteristics of some Nitisol profiles were investigated. In total 12 sample profiles were described and soil samples were collected from each of the identified master horizon. Soil physical characteristics evaluated were particle size distribution, structural aggregate stability, water holding capacity and bulk density. Chemical characteristics determined were exchangeable bases and cation exchange capacity, soil pH and the contents of organic carbon (OC), total nitrogen (TN), available phosphorus (AP) and some micronutrients.
\end{abstract}

Results: Among the physical characteristics, land use and slope significantly $(\mathrm{p}<0.05)$ affected particle size distribution and plant available water content. The mean sand (28\%) and silt (26\%) particles in the intensive cereal system were significantly $(p<0.05)$ higher compared to $15 \%$ sand and $18 \%$ silt in the agroforestry system. Conversely, the mean values of fine grained texture materials including 39\% fine sand, $42 \%$ fine silt and $67 \%$ clay in the agroforestry system were significantly higher than $30 \%$ fine sand, $21 \%$ fine silt and $46 \%$ clay in the cereal system. Similarly, the lower slope had significantly ( $p<0.05$ ) higher fin texture materials (39\% fine sand, 30\% fine silt, and 63\%) clay) compared to $17 \%$ fine sand, $14 \%$ fine silt and $51 \%$ clay fractions in the upper slope. The proportion of water stable aggregate (WSA) were highlight (63-94\%) and there was no significant difference between land types and slope classes. Following from high structural aggregate stability, the soils have high water holding capacity that ranged from 22 to $32 \%$ at PWP to $34-49 \%$ at FC while plant available water content (AWC) was in the $120-230 \mathrm{~mm} \mathrm{~m}^{-1}$ range. Considering the chemical characteristics, land use significantly affected soil pH, total nitrogen (TN), exchangeable magnesium $\left(\mathrm{Mg}^{2+}\right)$, potassium $\left(\mathrm{K}^{+}\right)$, percent base saturation (PBS), and available micro nutrients -iron $\left(\mathrm{Fe}^{2+}\right)$, manganese $\left(\mathrm{Mn}^{2+}\right)$ and zinc $\left(\mathrm{Zn}^{2+}\right)$. The mean $\mathrm{pH}$ value (5.29) in the intensive cereal system strongly acidic while the $\mathrm{pH}$ value for the agroforestry system (6.12) was taken moderately acidic. The mean OC content was 2.0 and $2.1 \%$ for the intensive cereal and agroforestry systems that were rated very low. The mean TN values were 0.15 and $0.22 \%$ for intensive cereal and agroforestry systems that were taken as low to very low. Similarly the mean values for AP were 8 and $10 \mathrm{mg} \mathrm{kg}^{-1}$ for cereal and agroforestry systems that were rated low. On the other hand, the CEC, exchangeable bases $\left(\mathrm{Ca}^{2+}, \mathrm{Mg}^{2+}\right.$, $\mathrm{K}^{+}$) and PBS of the soil were rated high while $\mathrm{Na}^{+}$appeared only in trace amount, and there was no significant difference between land use type and slope classes except for $\mathrm{Mg}^{2+}, \mathrm{K}^{+}$and PBS. Mean values of $\mathrm{Mg}^{2+}$ and $\mathrm{K}^{+}(15$ and 3 $\left.\mathrm{cmol}(+) \mathrm{kg}^{-1}\right)$ and PBS (75\%) in the agroforestry system were significantly higher than those in the cereal system (6 and $1.6 \mathrm{cmol}(+) \mathrm{kg}^{-1}$ of $\mathrm{Mg}^{2+}$ and $\mathrm{K}^{+}$and $\left.51 \% \mathrm{PBS}\right)$. Among micronutrients, land use significantly $(\mathrm{p}<0.05)$ affected

*Correspondence: Eyasu.elias@aau.edu.et; eyuelias@gmail.com

Centre for Environmental Science, College of Natural and Computational

Sciences, Addis Ababa University, Addis Ababa, Ethiopia 
available $\mathrm{Fe}^{2+}, \mathrm{Mn}^{2+}$ and $\mathrm{Zn}^{+}$. The mean values of $\mathrm{Fe}^{2+}\left(97 \mathrm{mg} \mathrm{kg}^{-1}\right)$ and $\mathrm{Mn}^{2+}\left(68 \mathrm{mg} \mathrm{kg}^{-1}\right)$ in the agroforestry system were taken as excessively high while they were moderately sufficient $\left(37,39 \mathrm{mg} \mathrm{kg}^{-1}\right.$, respectively) in the cereal system. Slope effects were significant for OC, TN and AP having higher mean values (2.5\% OC, 0.22\% TN and $17 \mathrm{mg} \mathrm{kg}^{-1} \mathrm{AP}$ ) in the lower slope than in the upper slope (1.5\% OC, $0.13 \% \mathrm{TN}$ and $8 \mathrm{mg} \mathrm{kg}^{-1} \mathrm{AP}$ ).

Conclusion: Land use and slope had significant effect on some soil physical and chemical characteristics. The land use practices in the intensive cereal system are adversely affecting important soil characteristics as compared to the soil under the agroforestry system. These include alteration of particle size distribution, strongly acidic soil reaction, organic matter and nutrient depletion (N, $\mathrm{P}, \mathrm{K}$ and $\mathrm{Zn}$ ) and low plant available water content. Among the inappropriate land use practices include repeated cultivation to create fine seedbed that predisposes the soil to erosion, unbalanced fertilizer application, rotation of maize with potato that are depleting soil nutrient stocks (e., K and Zn), and removal of crop residues from fields. Therefore, a more balanced fertilizer blend application that contain N, P, K and $\mathrm{Zn}$ combined with liming to raise soil $\mathrm{pH}$, organic matter management and integrated soil water conservation are recommended.

Keywords: Land use, Nitisol profiles, Physical and chemical characteristics, Slope

\section{Background}

In Ethiopia, diversities in state factors such as topography, parent materials, climate and vegetation have resulted in the development of 18 soil types of which Nitisols are among the most extensive soils (FAO 1984; Elias 2016). Indeed, more than half of all the Nitisols of tropical Africa are found in the Ethiopian highlands followed by Kenya, Congo and Cameroon (Stocking 1988; FAO 2001). Different reports provide different area estimates of Nitisols in the Ethiopian highlands (FAO 1984; Zewdie 2013). The most recent survey puts the extent of Nitisols to cover about one million hectares that account for $31 \%$ of the agricultural lands in the Ethiopian highlands (Elias 2016). The soils are particularly extensive in the south-western and north-central highlands representing 64 and $25 \%$ of the agricultural landmass, respectively (Fig. 1). Nitisols are among the most productive agricultural soils along with Vertisols, Luvisols, and Planosols (Stocking 1988). They support the bulk of the cereal and livestock production in the Ethiopian highlands. More importantly, the production of coffee (Cofea arabica), the most important export commodity in Ethiopia, relies almost exclusively on Nitisols. In addition, the large proportion of tea production comes from strongly acidic Nitisols in the western part of the country (Elias 2002).

However, soil nutrient and organic matter depletion, acidification and soil erosion losses as result of inappropriate land use practices have become major cause of concern for agricultural soils in the Ethiopian highlands (Elias 2002; IFPRI 2010). In particular, due to the land form of occurrence (high to mountains relief hills with moderately steep slopes) and intensive cereal cultivation and cattle grazing, Nitisols have become prone to degradation in spite of their high structural aggregate stability to resist erosion (FAO 2001; Elias 2016). Land use changes and cultivation of fields without adequate conservation practices, low levels of fertilizer application and failure to recycle crop residues are among the causal factors. Traditionally, soil fertility is replenished through fallow cycles of up to 20 years during which time the land gains fertility through atmospheric deposition, biological fixation and the supply of fresh organic matter and nutrients to the soils (Smaling and Braun 1996; Elias et al. 1998). As population increases, fallow periods are either shortened or abandoned altogether resulting in continuous cultivation of the land. In some parts of the Ethiopian highlands, steep slopes with gradients as steep as $50 \%$ are cultivated without installing adequate conservation measures (Assen and Tegene 2008). Often, resource-poor farmers have a short time horizon, i.e., they are primarily concerned with the crop and animal production of the forthcoming season than the long-term productivity of the soil. Longer-term processes that adversely affect agricultural sustainability such as depletion of soil organic matter and nutrient stocks are less visible and perhaps less noteworthy by farmers (Hailu et al. 2015; Elias 2016).

As result, land degradation has become a major policy concern in Ethiopia that is experiencing one of the highest rates of soil erosion and nutrient depletion in Africa (Elias et al. 1998; Hailu et al. 2015; Laekemariam et al. 2016). The rate of soil erosion losses, 130 tons $\mathrm{ha}^{-1}$ for cultivated fields, was estimated to be one of the highest in Africa (FAO 1986; Elias 2016). The depletion rate of macronutrients, $-122 \mathrm{~kg} \mathrm{~N} \mathrm{ha}^{-1},-13 \mathrm{~kg} \mathrm{P} \mathrm{ha}^{-1}$ and $-82 \mathrm{~kg} \mathrm{~K} \mathrm{ha}^{-1}$, was estimated to be high (Haileslassie et al. 2005). The field level nutrient balances on Nitisols reported from southern Ethiopia $(-102,-45$ and $-67 \mathrm{~kg} \mathrm{~N}, \mathrm{P}$ and $\mathrm{K} \mathrm{ha}^{-1}$ ) are even more threatening (Elias 2002).

Among the unsustainable land use practices farmers that fuel soil degradation include low and unbalanced 


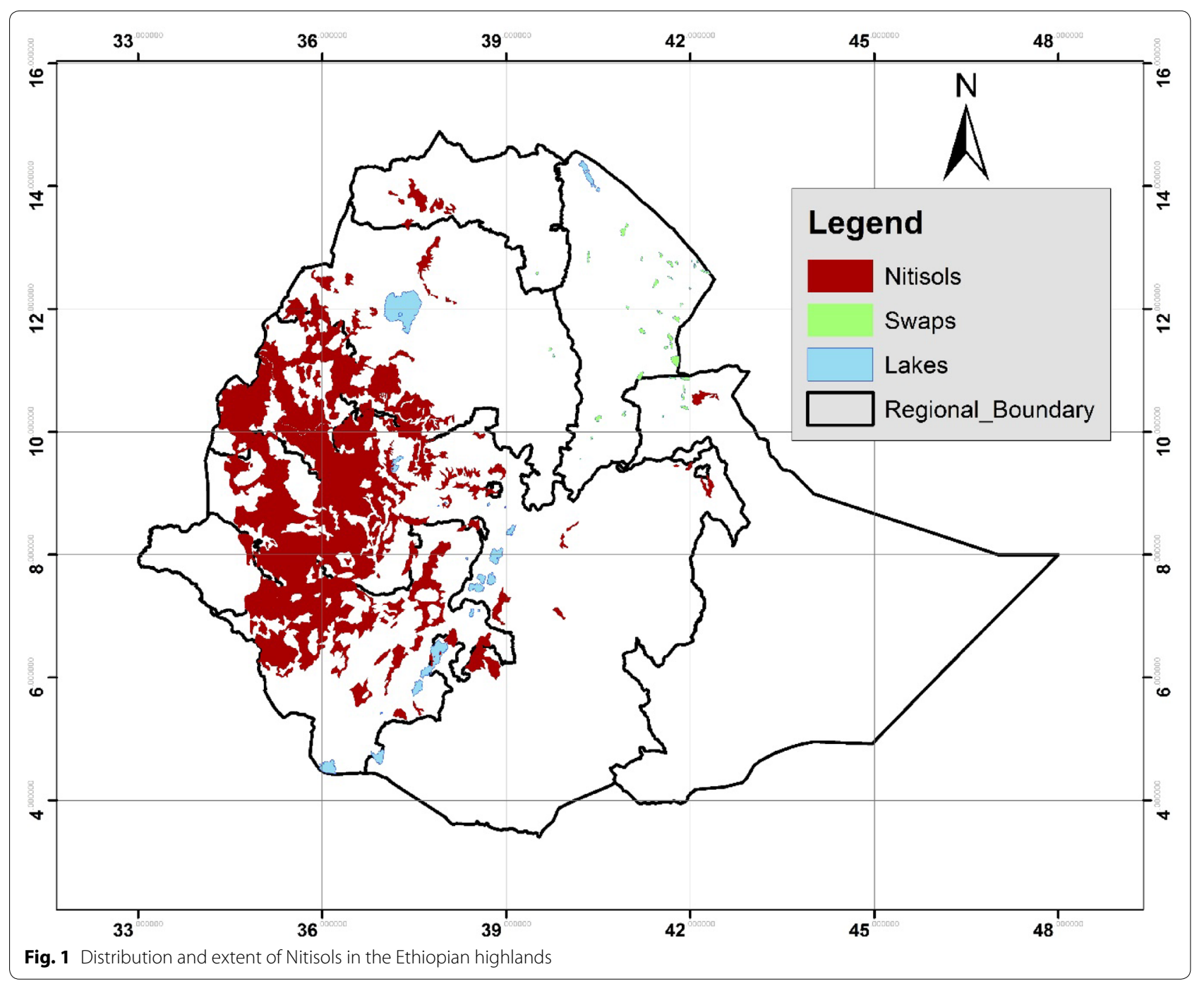

fertilizer application leading to mining of soil nutrient stocks, complete removal of crop residues, and dung burning as household energy rather than recycling to augment soil fertility and intensive tilling to create smooth seed bed for small cereals that predisposes the soil to erosion (Elias 2002; Hailu et al. 2015). In addition, research reports suggest that continued application of nitrogen and phosphorus alone would accentuate the uptake and deficiency of other nutrients that are not supplied in the fertilizer. Application of $\mathrm{N}$ and $\mathrm{P}$ fertilizer alone would particularly increase the uptake of micronutrients (e.g., Zn, Bo, Mn) and eventually depletes them unless included in the fertilizer scheme (FAO 2006b; Elias 2016).

The government of Ethiopia has initiated various interventions to arrest soil degradation primarily mass mobilisation and participatory watershed protection and fertilizer extension. Until 2015, a blanket recommendation of $150 \mathrm{~kg}$ DAP ha ${ }^{-1}$ (Di-ammonium Phosphate: 18\%
$\left.\mathrm{N}, 46 \% \mathrm{P}_{2} \mathrm{O}_{5}\right)$ and $100 \mathrm{~kg} \mathrm{ha}^{-1}$ of urea $(46 \% \mathrm{~N})$ has been promoted. In actual practice, the recommended rate is applied only in some high potential highland cereal zones such as west Gojam, central Shewa and Arsi-Bale highlands while the national average rate of $43 \mathrm{~kg}$ urea ha ${ }^{-1}$ and $65 \mathrm{~kg} \mathrm{DAP} \mathrm{ha}^{-1}$ is at best low (Elias 2016). Since 2015, the government of Ethiopia initiated preliminary fertilizer blend formulas in which new compound fertilizer (NPS: $19 \% \mathrm{~N}, 38 \% \mathrm{P}_{2} \mathrm{O}_{5}, 7 \% \mathrm{~S}$ ) was introduced to replace DAP for blending with potassium $(\mathrm{K})$ and some micronutrients chiefly zinc $(\mathrm{Zn})$ and boron (B). This has resulted in the formulation of two poplar blends, namely, Zinc blend $\left(14 \% \mathrm{~N}, 23 \% \mathrm{P}_{2} \mathrm{O}_{5}, 8.2 \% \mathrm{~S}\right.$, and $\left.1.2 \% \mathrm{Zn}\right)$ and zinc-boron blend $\left(14 \% \mathrm{~N}, 21 \% \mathrm{P}_{2} \mathrm{O}_{5}, 15 \% \mathrm{~K}_{2} \mathrm{O}, 6.5 \% \mathrm{~S}\right.$, $1.3 \% \mathrm{Zn}$ and $0.5 \% \mathrm{~B}$ ) (Karltun et al. 2013). Efforts are underway to prepare regional soil fertility maps to guide fertilizer recommendations but site, crop and soil specific fertilizer rate recommendations are yet to be developed. This remains crucially important to maximize crop 
production while at the same time maintaining soil quality (through balanced nutrition) and reversing nutrient depletion.

A more nuanced approach should, therefore, take into considerations of the spatial diversities in soil nutrient stocks and land use practices, which are factors driving crop demand for soil nutrients (Elias 2016). On the one hand, studies suggest that soil fertility depletion and land use effects on soil physical and chemical characteristics vary strongly across land use type, slope gradients and soil types (Gebreselassie et al. 2015; Hailu et al. 2015; Laekemariam et al. 2016). On the other hand, reports suggest that land use effects vary considerably with soil types with some soils being more prone to physical and chemical deterioration than others (USDA-NRCS 2014). For example, Gebreselassie et al. (2015) working on Luvisols in the central highlands of Ethiopia reported significantly higher mean values of organic matter, TN and exchangeable bases in the lower slope than in the upper slopes. Information on the effects of land use type and slope class on the physical and chemical characteristics of Nitisol is largely lacking for the Ethiopian highlands thus impinging up on more nuanced soil fertility management decisions. Such information is crucially important for planning soil management strategies that curb the adverse effects of inappropriate land use on soil characteristics. Hence, this study was set out to evaluate how Nitisols profiles occurring in upper and lower slope positions respond to different land use types in terms of their physical and chemical characteristics.

\section{Soil sites and methods}

\section{Location, landform and geology}

The study was conducted in two districts (Jabi Tehnan and Gera) representing the cereal and agroforestry systems in the north-central and south-western highlands where Nitisols are most dominant (Fig. 1). The landforms in the north central highlands are characterized by the undulating to rolling high plateaus with scattered moderate relief hills, dissected side slopes and river gorges including the popular Blue Nile gorge (Elias 2016). The landform in the south-western highlands is characterized by moderate to high relief mountains and undulating to rolling hills. Trap Series volcanic rocks (basalt, trachyte, ignimbrite ash flows, and tuff) predominate the high plateau landscapes in the north-central highlands. Basaltic basement complex was overflown by lavas in the Tertiary-Quaternary volcanic rocks resulting in geologically young soils that are developed over pre-weathered materials (Elias 2016). According to Davidson (1983), the geological materials building the soil profiles in the south-western highlands are recent pyroclastic deposits over the volcanic rocks of the late Eocene to the late Oligocene period. Major parent materials include basic rocks such as alkali-olivine basalts, gabbro, amphibole mixed with more recent flood basalts and tuff.

\section{Climate}

Much of the Nitisol areas in the Ethiopian highlands are characterized by humid to sub-humid agro-climatic conditions (Elias 2016). The main monsoon rains over much of the Ethiopian highlands are influenced by the Inter-Tropical Convergence Zone (ITCZ) weather system as blown from the Atlantic Ocean. The average annual rainfall ranges between 1300 and $1600 \mathrm{~mm}$ in the north-central highlands that falls between June and September months. The rainy season is much extended in the south-western highlands spanning from February to October with average annual rainfall in the range of 1800-2000 mm. The mean annual air temperature in much of the Ethiopian highlands is $22-25^{\circ} \mathrm{C}$ (Elias 2016). According to Eswaren (1988) the Ethiopian highlands are categorized by udic soil moisture and hyperthermic soil temperature regimes.

\section{Farming system and land use types}

In the intensive cereal system, five major cereals form the staples for the population: tef (Eragrostis tef (Zucc), maize (Zea mais), wheat (Triticum aestivum), barley (Hordeum vulgarae) and sorghum (Sorghum bicolor). Maize-potato rotation is the main form of crop rotation and free range grazing in crop fields after harvest is commonly practiced. In the agroforestry based system, the fields are divided into home gardens and distant outfields. In the home gardens, enset ${ }^{2}$ (Enset ventricosum or Musa ensete), coffee and shade trees (e.g., Cordia africana) and fruit trees such as avocado (Persia americana) and mango (Mangifera indica) are typical features with undergrowth of root crops, tubers and species. The distant out fields are planted to cereals (maize, wheat, tef) that are cultivated in rotation with legumes such as faba bean (Vicia faba), haricot bean (Phaseulus vulgaris) and soybean (Glycinemax sp.) in certain places. Trees such as Codia africana, Milletia ferruginea, Croton macrostachyus, and various species of acacia are interspersed in the crop fields providing fresh supply of organic matter in the form of leaf litter to the soil.

\footnotetext{
${ }^{1}$ Tef (Eragrostis tef) is small cereal cultivated in Ethiopia for its grain that is used to make the most favorite national food-Enjera. The plant rarely known as food staple outside of Ethiopia.

2 Enset (Enset ventricosum or Musa ensete otherwise called false banana) is a plant having pseudo-stem and corm that are pulped for food and fiber that provides subsistence for about 10 million people in the south-western highlands of Ethiopia.
} 


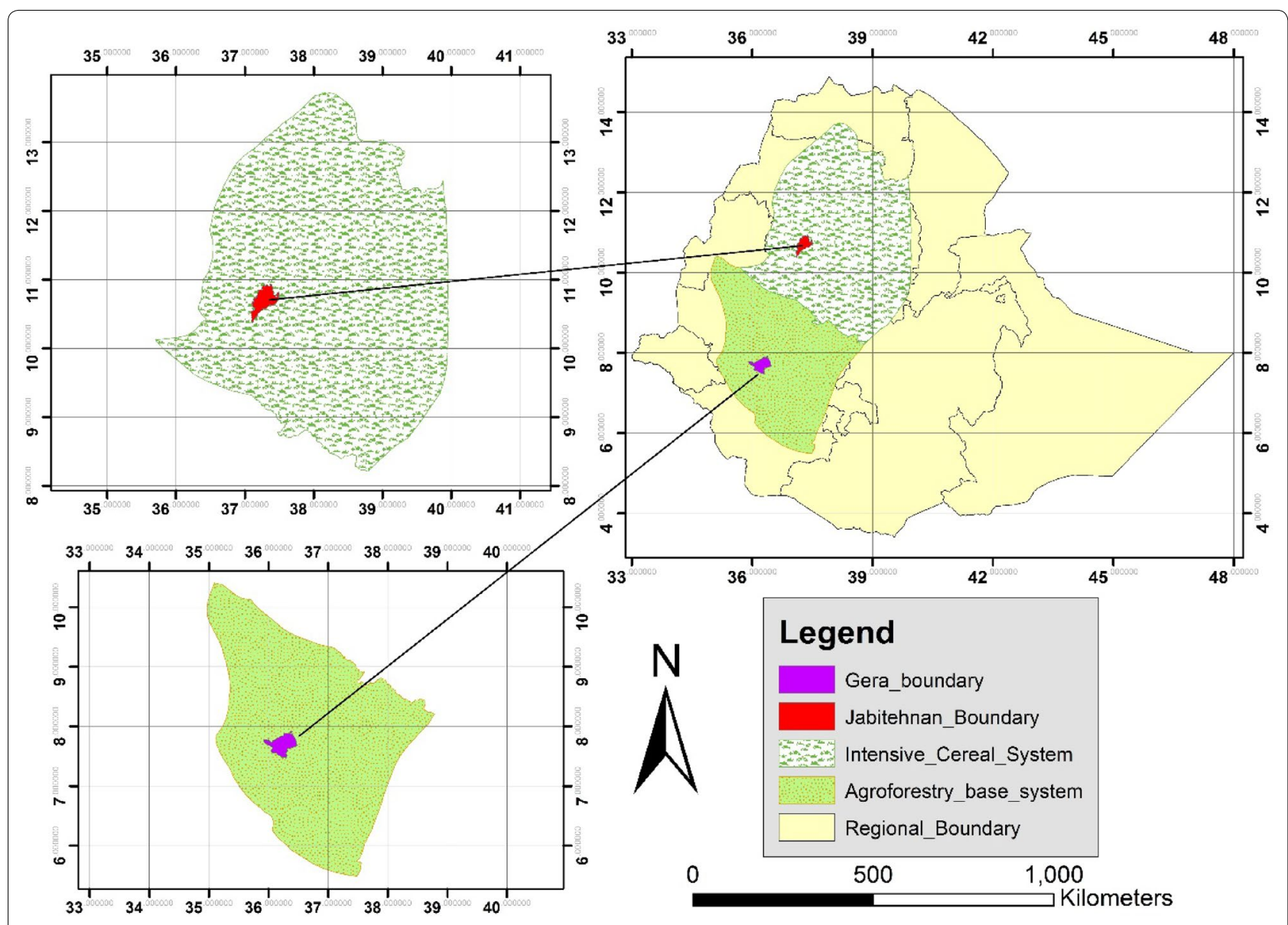

Fig. 2 Location map of the study sites showing the major land use types and study districts

Soil fertility management practices are also distinctly differentiated according to the farming system. In the intensive cereal system the majority of farmers apply $150 \mathrm{~kg}$ DAP ha ${ }^{-1}$ and $100 \mathrm{~kg}$ urea ha ${ }^{-1}$ as per the extension recommendation thus, supplying 73-69 kg N-P $\mathrm{P}_{2} \mathrm{O}_{5} \mathrm{ha}^{-1}$. In the agroforestry system, the home gardens receive the application of farm yard manure and household refuse while the outer fields are treated with 75-50 kg DAP-urea $\mathrm{ha}^{-1}$, thus, supplying $37-35 \mathrm{~kg} \mathrm{~N}-\mathrm{P}_{2} \mathrm{O}_{5} \mathrm{ha}^{-1}$. This is supplemented by application of on average 1.5-2.0 ton ha ${ }^{-1}$ of compost as well as systematic manuring through kraaling $^{3}$ system (Elias 2016).

\section{Soil sampling units}

Following the intervention sites of the project ${ }^{4}$ that supported the study and using the soil landscape map (Elias

\footnotetext{
${ }^{3}$ During the dry season, cattle kraals are set up in crop fields that rotate to new fields every two weeks thus systematically distributing animal dung over much of the cultivated outfields.

${ }^{4}$ The Dutch project, Capacity building for scaling up of evidence based best practices in Ethiopia (CASCAPE for short) has supported the study.
}

2016), Jabi Tehnan (west Gojam) and Gera (Jimma area) districts were selected representing the intensive cereal and agroforestry systems, respectively (Fig. 2). In each district, a "representative" sub-watershed was selected using the slope map that was prepared following slope classes categorization provided in FAO (2006a). Accordingly, Jimat sub-watershed in Jimat Peasant Association of Jabittehnan district and Garee Weychara sub-watershed in Wanja Kersa peasant association of Gera district were delineated (Fig. 3). The soil-landscape map of the two districts indicate that about $80 \%$ of the Nitisols are found within lower limits of $2-5 \%$ (gently sloping) and upper limits of $15-30 \%$ (moderately steep slope). For this reason, the study delineated these two slope classes as lower and upper limits for soil profile sampling. In each slope, three sample profiles were described giving a total sample of 12 profiles (Fig. 3). In the agroforestry system, profiles were opened in the distant outfields as digging pits inside the gardens is culturally not allowable. Table 1 provides the list of profiles, their geographic location, slope class and elevation. Soil profile pits were opened to 


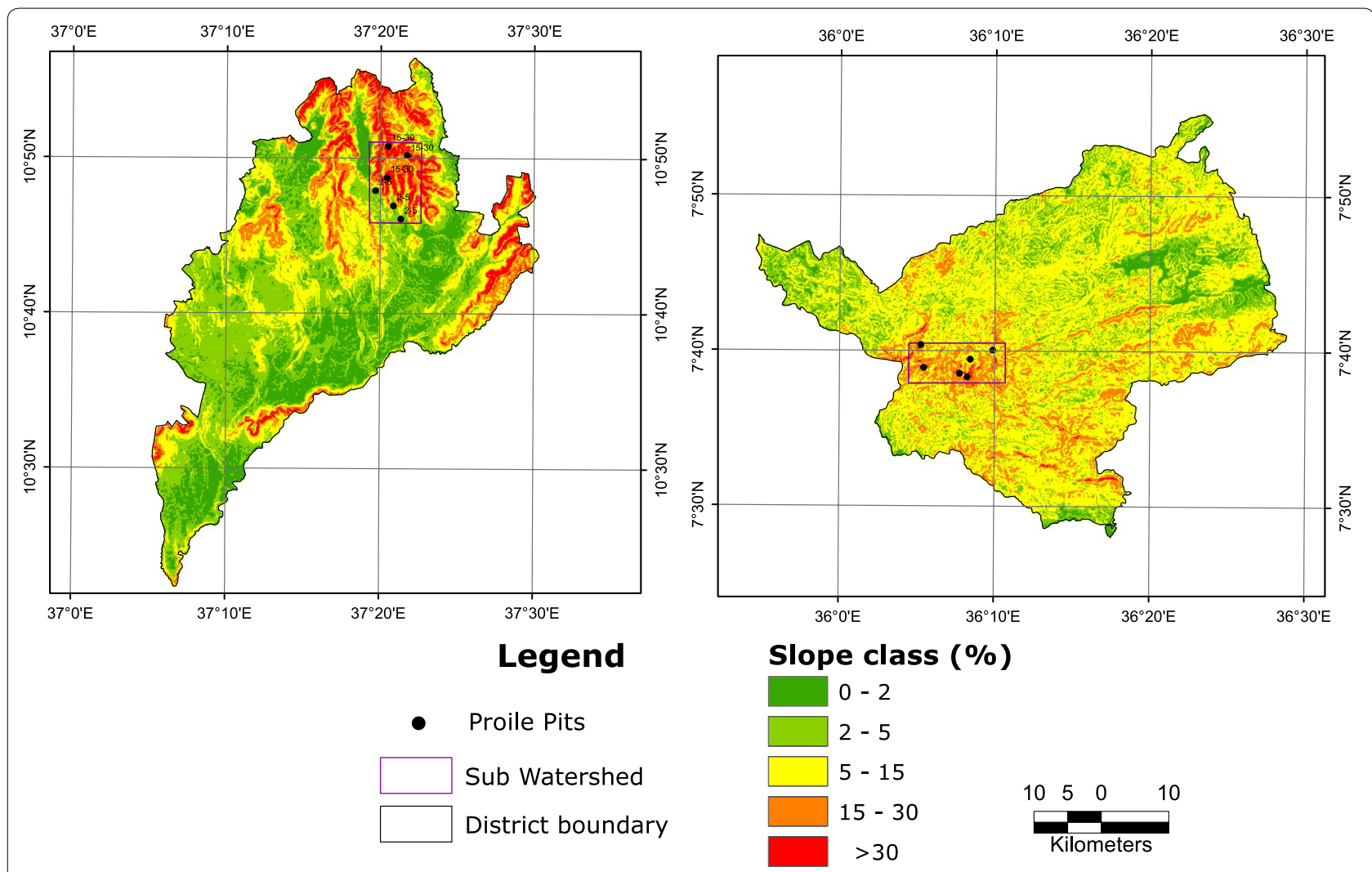

Fig. 3 Slope map of Jabi Tehnan district (left) and Gera district (right) showing sub-watershed and soil sampling units

Table 1 Geographic location, slope class, elevation and land use types in the profiles sites

\begin{tabular}{|c|c|c|c|c|}
\hline Profile ID & Latitude & Longitude & Slope (\%) & Altitude $(\mathrm{m})$ \\
\hline \multicolumn{5}{|c|}{ Intensive cereal-livestock system (north-central highlands) } \\
\hline ET_AJJIP001 & $10^{\circ} 39^{\prime} 33.407^{\prime \prime} \mathrm{N}$ & $37^{\circ} 19^{\prime} 29.398^{\prime \prime} \mathrm{E}$ & $2-5$ & 2790 \\
\hline ET_AMAMP001 & $11^{\circ} 24^{\prime} 26.593^{\prime \prime} \mathrm{N}$ & $37^{\circ} 3^{\prime} 36.276^{\prime \prime} \mathrm{E}$ & $2-5$ & 2800 \\
\hline ET_ASAA-P001 & $11^{\circ} 21^{\prime} 49.326^{\prime \prime} \mathrm{N}$ & $36^{\circ} 57^{\prime} 8.624^{\prime \prime} \mathrm{E}$ & $2-5$ & 2446 \\
\hline ET_ASAA-P002 & $11^{\circ} 20^{\prime} 21.373^{\prime \prime} \mathrm{N}$ & $36^{\circ} 55^{\prime} 52.203^{\prime \prime} \mathrm{E}$ & $15-30$ & 1946 \\
\hline ET_MTA-HBP1 & $9^{\circ} 26^{\prime} 23.008^{\prime \prime} \mathrm{N}$ & $41^{\circ} 42^{\prime} 56.008^{\prime \prime} \mathrm{E}$ & $15-30$ & 2272 \\
\hline ET_GIR-GGP3 & $8^{\circ} 11^{\prime} 36.640^{\prime \prime} \mathrm{N}$ & $36^{\circ} 56^{\prime} 27.632^{\prime \prime} \mathrm{E}$ & $15-30$ & 2954 \\
\hline \multicolumn{5}{|c|}{ Agroforestry-livestock system (south-western highlands) } \\
\hline ET_JIMG-SLP2 & $7046^{\prime} 36.005^{\prime \prime} \mathrm{N}$ & $36^{\circ} 24^{\prime} 33.012^{\prime \prime} \mathrm{E}$ & $2-5$ & 1917 \\
\hline ET_JIMG-WKP1 & $7047^{\prime} 05.003^{\prime \prime} \mathrm{N}$ & $36^{\circ} 22^{\prime} 17.011^{\prime \prime} \mathrm{E}$ & $2-5$ & 1932 \\
\hline ET_BAK-AGP3 & $8059^{\prime} 21.779^{\prime \prime} \mathrm{N}$ & $37012^{\prime} 21.316^{\prime \prime} \mathrm{E}$ & $2-5$ & 1665 \\
\hline ET_JIMLS-SP2 & $8^{\circ} 11^{\prime} 36.640^{\prime \prime} \mathrm{N}$ & $36^{\circ} 56^{\prime} 27.632^{\prime \prime} \mathrm{E}$ & $15-30$ & 1953 \\
\hline ET_JIMG-GCP2 & $7043^{\prime} 39.994^{\prime \prime} \mathrm{N}$ & $36^{\circ} 15^{\prime} 09.014^{\prime \prime} \mathrm{E}$ & $15-30$ & 2025 \\
\hline ET_ILUD-MMP1 & $8 \circ 29^{\prime} 07.994^{\prime \prime} \mathrm{N}$ & $36^{\circ} 20^{\prime} 05.014^{\prime \prime} \mathrm{E}$ & $15-30$ & 2163 \\
\hline
\end{tabular}

a depth of $200 \mathrm{~cm}$ (bedrock permitting) and the soil was described according to the FAO guidelines for soil description (FAO 2006a). Soil samples were taken from each of the identified genetic horizons for laboratory investigation.

\section{Soil analytical procedures}

A total of 53 samples were collected from 12 profiles and taken to the soil fertility lab of the Water Works Design and Supervision Enterprise (WWDSE) in Addis Ababa, Ethiopia. The analytical methods followed the standard 
Table 2 Particle size limits for coarse, medium and fine sand and silt fractions (USDA-NRCS 2014)

\begin{tabular}{lll}
\hline Particle size fraction & Sand $(\mathbf{0 . 0 5}-\mathbf{2} \mathbf{~ m m})$ & Silt $(\mathbf{0 . 0 0 2}-\mathbf{0 . 0 5} \mathbf{~ m m})$ \\
\hline Coarse & $0.8-0.40$ & $0.06-0.02$ \\
Medium & $0.4-0.20$ & $0.02-0.006$ \\
Fine & $0.2-0.06$ & $0.006-0.002$ \\
\hline
\end{tabular}

procedures as outlined in Van Reeuwijk (2006). The percentage of sand $(0.05-2.0 \mathrm{~mm})$, silt $(0.002-0.05 \mathrm{~mm})$ and clay $(<0.002 \mathrm{~mm})$ fractions of the fine earth $(<2 \mathrm{~mm})$ was determined using the modified sedimentation hydrometer procedure (Bouyoucos 1962). Particle grain size analysis to separate coarse, medium and fine sand and silt fractions was carried out following the procedures outlined in USDA-NRCS (2014). Particle size limits for the coarse, medium and fine fractions are given in Table 2. This was to evaluate the effect of land use and slope on particle size fractions which in turn have impact on erosion and management practices to be implemented. Soil aggregate stability test was conducted by wet sieving method as outlined in USDA-NRCS (2014). It involves abrupt submergence of air dry aggregates in water followed by wet sieving using $0.5 \mathrm{~mm}$ sieve. Figures reported are percentage of aggregates retained after wet sieving. Soil moisture contents $(\mathrm{w} / \mathrm{w}, \%)$ were determined by means of pressure membrane extractor at different pressure forces to the crushed samples (Baruah and Barthakur 1997). The field capacity (FC) was determined at $1 / 3$ bar and the permanent wilting point (PWP) at 15 bars for sieved and air dry soil samples. The plant available water content (AWC) was determined as the difference between FC (the upper limit) and PWP (the lower limit).

Soil $\mathrm{pH}$ was determined in water $\left(\mathrm{pH}-\mathrm{H}_{2} \mathrm{O}\right)$ using a 1:2.5 soil to water solution ratio with a $\mathrm{pH}$ meter as outlined in Van Reeuwijk (2006). Organic carbon (OC) content of the soil was analyzed using the Walkley and Black method (Nelson and Sommers 1982). Total nitrogen (TN) was analyzed according to the Macro-Kjeldahl method that involves digestion of the sample and a wet-oxidation procedure (Bremner and Mulvaney 1982). Available phosphorus (AP) content was determined using Olsen ${ }^{5}$

\footnotetext{
${ }^{5}$ In Ethiopia, the Olsen's $\mathrm{NaHCO}_{3}$ method (pH 8.5) is widely used for determining soil available P. A study on the evaluation of soil test methods for available phosphorus on 32 Ethiopian soils reported that the Olsen method followed by Warren and Cooke, and Truog methods is the best of the eight chemical methods they used to assess available P (Mamo and Hague (1991). This was further confirmed by Mamo, Christian and Heilig$\operatorname{tag}$ (2002) who found the magnitude of soil available P extraction in the order Truog $>$ CAL $>$ Olsen $>$ Bray II $>$ Warren and Cooke. Since Troug and CAL methods are not practiced in the analytical labs in Ethiopia, the Olsen, Cole, Watanabe and Dean (1954) remains the best method for available P-extraction in Ethiopia to date.
}

sodium bicarbonate extraction solution at $\mathrm{pH} 8.5$ (Olsen et al. 1954) and the amount of AP $\left(\mathrm{mg} \mathrm{kg}^{-1}\right)$ was determined by spectrophotometer (Van Reeuwijk 2006). Exchangeable cations and $\mathrm{CEC}\left(\mathrm{cmol}(+) \mathrm{kg}^{-1}\right)$ were determined by Ammonium Acetate method at $\mathrm{pH}$ 7. In the leachate, Exchangeable $\mathrm{Ca}^{2+}$ and $\mathrm{Mg}^{2+}$ were determined using Atomic Absorption Spectrophotometer (AAS) and $\mathrm{Na}^{+}$and $\mathrm{K}^{+}$by flame photometer as outlined in Van Reeuwijk (2006). The contents of selected micronutrients $\left(\mathrm{Fe}^{2+}, \mathrm{Mn}^{2+}, \mathrm{Zn}^{2+}\right.$ and $\left.\mathrm{Cu}^{2+}\right)$ was determined using the di-ethylene tri-amine-penta-acetic acid (DTPA) extraction method (Tan 1996).

\section{Statistical analysis and data presentation}

Descriptive statistics was applied and mean values for the surface horizons of all profiles investigated were computed by means of weighted average. The presence of significant difference in mean values between the two land use types and slope classes was tested using paired $\mathrm{T}$ test in SPSS (Statistical Package for Social Science) software Version 23. The results of the Paired T test analysis present the weighted mean values of all profiles investigated. Full profile information (analytical data) on physical and chemical characteristics is presented for four sample profiles representing the two land use types and slope classes.

\section{Results and discussion}

\section{Soil physical characteristics as affected by land use type and slope class}

The soils are clayey with clay content ranging from 51 to $55 \%$ in the A-horizon and from 58 to $72 \%$ in the B-horizon (Table 3). The clay enrichment in the B-horizon is as result of clay migration. The silt/clay ratio ranges from 0.28 to 0.41 in the A-horizon and from 0.22 to 0.41 in the B-horizon that were rated as high according to the ratings of Hazelton and Murphy (2007). This suggests the presence of weatherable mineral reserve in the soil. The bulk density was within $1.04-1.14 \mathrm{~g} \mathrm{~cm}^{-3}$ range in the A-horizon and $1.02-1.12 \mathrm{~g} \mathrm{~cm}^{-3}$ in the B-horizon. These values are below the critical values for agricultural use $\left(1.4 \mathrm{~g} \mathrm{~cm}^{-3}\right)$ suggested by Hillel (2004) indicating the absence of excessive compaction or restrictions for root development.

Land use and slope significantly $(\mathrm{p}<0.05)$ affected particle size distribution and plant available water contents. The mean values of fine grained texture materials including $39 \%$ fine sand, $42 \%$ fine silt and $67 \%$ clay in the agroforestry system were significantly higher than $30 \%$ fine sand, $21 \%$ fine silt and $46 \%$ clay in the cereal system (Tables 4,5 ). These findings suggest that although texture is an inherent property of the soil, it can be altered by land use practices over a longer period 
Table 3 Particle size distribution, textural class and bulk density of Nitisol sample profiles

\begin{tabular}{|c|c|c|c|c|c|c|c|}
\hline Horizon & Depth $(\mathrm{cm})$ & Sand (\%) & Silt (\%) & Clay (\%) & Silt/clay & Class & $\mathrm{BD}\left(\mathrm{g} / \mathrm{cm}^{3}\right)$ \\
\hline \multicolumn{8}{|c|}{ Profile 1: Intensive cereal upper slope (ET_ASAAP002) } \\
\hline Ap & $0-20$ & 30 & 19 & 51 & 0.28 & Sandy clay & 1.14 \\
\hline$A B$ & $20-40$ & 26 & 16 & 58 & 0.27 & Clay & 1.07 \\
\hline Bt1 & $40-80$ & 22 & 18 & 60 & 0.30 & Clay & 1.02 \\
\hline Bt2 & $80-200$ & 27 & 11 & 62 & 0.20 & Clay & 1.20 \\
\hline \multicolumn{8}{|c|}{ Profile 2: Intensive cereal lower slope (ET_AJJIP001) } \\
\hline Ap & $0-20$ & 14 & 21 & 63 & 0.35 & Clay & 1.12 \\
\hline$A B$ & $20-42$ & 12 & 21 & 67 & 0.31 & Clay & 1.10 \\
\hline Bt1 & $42-90$ & 12 & 18 & 70 & 0.26 & Clay & 1.10 \\
\hline Bt2 & $90-200$ & 10 & 20 & 72 & 0.27 & Clay & 1.10 \\
\hline \multicolumn{8}{|c|}{ Profile 3: Agroforestry upper slope (ET_JIMLS-SP2) } \\
\hline Ah & $0-12$ & 23 & 23 & 55 & 0.41 & Clay & 1.14 \\
\hline BA & $12-30$ & 13 & 23 & 63 & 0.36 & Clay & 1.12 \\
\hline Bt1 & $30-0$ & 12 & 26 & 61 & 0.43 & Clay & 1.12 \\
\hline Bt2 & $90-145$ & 12 & 29 & 60 & 0.48 & Clay & 1.04 \\
\hline Bt3 & $145-200$ & 12 & 27 & 62 & 0.43 & Clay & 1.06 \\
\hline \multicolumn{8}{|c|}{ Profile 4: Agroforestry lower slope (ET_JIM-G-SLP2 } \\
\hline Ap & $0-10$ & 17 & 37 & 56 & 0.33 & Clay & 1.04 \\
\hline$A B$ & $10-30$ & 14 & 22 & 64 & 0.15 & Clay & 1.02 \\
\hline Bt1 & $30-60$ & 13 & 21 & 66 & 0.32 & Clay & 1.04 \\
\hline $\mathrm{Bt} 2$ & 60-105 & 11 & 22 & 63 & 0.42 & Clay & 1.07 \\
\hline Bt3 & 105-180 & 8 & 27 & 66 & 0.41 & Clay & 1.04 \\
\hline
\end{tabular}

$B D$ bulk density

of time (Schaetzl and Anderson 2005). Slope effect was also significant for particle size distribution. The mean values of fine sand (39\%), fine silt (30\%) and clay (63\%) in the lower slope were significantly $(\mathrm{p}<0.05)$ higher than mean values in the upper slope-17\% fine sand, $14 \%$ fine silt and $51 \%$ clay in the upper slope (Table 6). The findings suggest residual accumulation of coarser particles and removal of finer particles from in the upper slopes by runoff water and its deposition in the lower slopes. The result is in agreement with the findings of Gebreselassie et al. (2015) and Gebrekidan and Negassa (2006) that reported increasing trends of coarse fractions with increasing slope and increasing clay fractions with decreasing slope gradients.

Soil structural aggregate stability has a key role in the functioning of soil such as water retention, aeration, infiltration and therefore resistance to erosion (Abrishamkesh et al. 2010; USDA-NRCS 2014). The man values of water stable aggregate (WSA), the proportion of structural aggregates retained after wet sieving in $0.5 \mathrm{~mm}$ sieve, were 79 and $87 \%$ for the intensive cereal and agroforestry systems, respectively (Table 5). According to the ratings of Hazelton and Murphy (2007), the WSA was rated as very high and were not significantly different between land use types (Table 7). This indicates that Nitisols have little water dispersible aggregates and hence they are fairly resistant to erosion. This is part of the reason why the Nitisols remained deep and productive in spite of centuries of intensive cultivation and severe erosion hazards in the Ethiopian highlands (Elias 2016).

The water content of the soil at FC (1/3 bar) and PWP (15 bar) were 35 and $23 \%$ in the cereal system and 37 and $24 \%$ in the agroforestry system (Table 5). According to the rating of Hazelton and Murphy (2007), the water content at FC and PWP were rated as high while AWC was in the medium to high range. The generally favourable water holding capacity of the soil can be attributed to high clay content, well-developed soil structural aggregates and reasonably good organic matter contents of the soils. The result is in agreement with another report from Welega, western Ethiopia that found higher water holding capacity for soils with higher clay content (Chimdi et al. 2012). On the other hand, the mean AWC in the agroforestry system $(135 \mathrm{~mm} / \mathrm{m})$ was significantly higher than that in the cereal system $(112 \mathrm{~mm} / \mathrm{m})$ suggesting differences in particle grain size distribution and organic matter content. 
Table 4 Grain size fractionation of sand $(>0.05 \mathrm{~mm})$ and silt $(0.05-0.002 \mathrm{~mm})$ particles $(\%)$

\begin{tabular}{|c|c|c|c|c|c|c|c|}
\hline Horizon & Depth $(\mathrm{cm})$ & CS & MS & FS & CSi & MSi & $\mathrm{FSi}$ \\
\hline \multicolumn{8}{|c|}{ Profile 1: Intensive cereal upper slope (ET_ASAAP002) } \\
\hline Ap & $0-20$ & 62 & 20 & 18 & 52 & 27 & 21 \\
\hline$A B$ & $20-40$ & 64 & 15 & 21 & 66 & 20 & 14 \\
\hline Bt1 & $40-80$ & 62 & 22 & 16 & 45 & 20 & 35 \\
\hline Bt2 & $80-200$ & 58 & 21 & 21 & 56 & 27 & 17 \\
\hline \multicolumn{8}{|c|}{ Profile 2: Intensive cereal lower slope (ET_AJJIP001) } \\
\hline Ap & $0-20$ & 13 & 13 & 64 & 39 & 18 & 43 \\
\hline$A B$ & $20-42$ & 12 & 22 & 66 & 20 & 25 & 55 \\
\hline Bt1 & $42-90$ & 18 & 20 & 62 & 28 & 15 & 55 \\
\hline Bt2 & $90-200$ & 16 & 22 & 62 & 13 & 24 & 63 \\
\hline \multicolumn{8}{|c|}{ Profile 3: Agroforestry upper slope (ET_JIMLS-SP2) } \\
\hline Ah & $0-12$ & 45 & 21 & 34 & 55 & 25 & 25 \\
\hline BA & $12-30$ & 50 & 18 & 32 & 68 & 23 & 11 \\
\hline Bt1 & $30-90$ & 48 & 20 & 32 & 51 & 34 & 15 \\
\hline Bt2 & $90-145$ & 42 & 35 & 23 & 30 & 42 & 28 \\
\hline Bt3 & $145-200$ & 45 & 27 & 28 & 44 & 36 & 20 \\
\hline \multicolumn{8}{|c|}{ Profile 4: Agroforestry lower slope (ET_JIM-G-SLP2) } \\
\hline Ap & $0-10$ & 12 & 23 & 65 & 20 & 14 & 66 \\
\hline$A B$ & $10-30$ & 10 & 28 & 62 & 39 & 19 & 42 \\
\hline Bt1 & $30-60$ & 7 & 30 & 63 & 29 & 23 & 57 \\
\hline Bt2 & 60-105 & 17 & 25 & 63 & 29 & 20 & 51 \\
\hline Bt3 & $105-180$ & 15 & 30 & 55 & 28 & 24 & 48 \\
\hline
\end{tabular}

CS coarse sand, MS medium sand, FS fine sand; CSi coarse silt, MS medium silt, FSi fine silt

\section{Soil chemical characteristics as affected by land use and slope}

Tables 8 and 9 summarize important chemical characteristics of the sample profiles of Nitisols while mean values as affected by land use type and slope class are presented in Tables 10 and 11 . The mean $\mathrm{pH}$ values were 5.29 and 6.12 for the cereal and agroforestry systems (Table 8) which are statistically significantly $(\mathrm{p}<0.05)$ different. Based on the ratings of Hazelton and Murphy (2007), the soil $\mathrm{pH}$ is rated as strongly acidic and moderately acidic respectively. The strongly acidic soil reaction in the cereal system was attributed to intense leaching of bases and continued application of DAP and urea fertilizers. The base saturation 62 and $77 \%$ for the cereal and agroforestry systems that are significantly $(\mathrm{p}<0.05)$ different (Table 10). The implication is that there is more intense leaching of basic cations in the cereal system resulting in higher exchangeable acidity. In addition, the rate of fertilizer application in the cereal system $(100 \mathrm{~kg}$ urea and $150 \mathrm{~kg}$ DAP ha-1) was double the rate applied in the agroforestry system (i.e., $50 \mathrm{~kg}$ DAP and $75 \mathrm{~kg}$ urea ha ${ }^{-1}$ ). Previous research findings suggest that continuous application ammonia fertilizers such as DAP and urea can contribute to increased exchangeable acidity of the soil (Smaling and Braun 1996; Elias et al. 1998; Elias 2016).
The mean OC content was 2.0 and $2.1 \%$ for the intensive cereal and agroforestry systems (Table 10). Based on the ratings of Landon (1991), the OC of the soil was rated very low showing no significant difference between the land use types. On the other hand, slope effect was significant $(\mathrm{p}<0.05)$ with higher mean values $(2.5 \% \mathrm{OC})$ in the lower slope compared to $1.5 \%$ in the upper slope (Table 11). This is attributed to the movement of humus particles down slope with runoff water. The finding is in agreement with Gebreselassie et al. (2015) that reported increasing OC contents with decreasing slope.

The mean TN values, 0.15 and $0.22 \%$ for the intensive cereal and agroforestry systems, were rated low based on the ratings of Landon (1991) and significantly ( $p<0.05$ ) different between the two land use types. Higher TN content in the agroforestry system was due to crop residues addition and leaf litter accumulation from land use practices that added to N-mineralization. This is further elaborated by significantly lower $\mathrm{C} / \mathrm{N}$ ratios with mean value of 10 in the agroforestry system compared to 18 in the intensive cereal system (Table 10). Although rate of decomposition was not measured in this study, the significantly higher $\mathrm{C} / \mathrm{N}$ ratios are indicative of somewhat depressed microbial 
Table 5 Structural aggregate stability and water holding capacity of Nitisol sample profiles

\begin{tabular}{|c|c|c|c|c|c|}
\hline \multirow[t]{2}{*}{ Horizon } & \multirow[t]{2}{*}{ Depth (cm) } & \multirow{2}{*}{$\begin{array}{l}\text { Water stable aggregates } \\
(\%)\end{array}$} & \multicolumn{3}{|c|}{ Water holding capacity (\%) } \\
\hline & & & FC (1/3 bar $)$ & PWP (15 bar) & $\operatorname{AWC}\left(\mathrm{mm} \mathrm{m}^{-1}\right)$ \\
\hline \multicolumn{6}{|c|}{ Profile 1: Intensive cereal upper slope (ET_ASAAP002) } \\
\hline Ap & $0-20$ & 63 & 34 & 22 & 120 \\
\hline$A B$ & $20-40$ & 70 & 35 & 23 & 120 \\
\hline Bt1 & $40-80$ & 79 & 38 & 26 & 120 \\
\hline Bt2 & 80-200 & 76 & 40 & 28 & 120 \\
\hline \multicolumn{6}{|c|}{ Profile 2: Intensive cereal lower slope (ET_AJJP001) } \\
\hline Ap & $0-20$ & 85 & 38 & 26 & 120 \\
\hline$A B$ & $20-42$ & 88 & 42 & 29 & 130 \\
\hline Bt1 & $42-90$ & 89 & 43 & 30 & 130 \\
\hline Bt2 & $90-200$ & 91 & 46 & 31 & 150 \\
\hline \multicolumn{6}{|c|}{ Profile 3: Agroforestry upper slope (ET_JIMLS-SP2) } \\
\hline Ah & $0-12$ & 78 & 39 & 25 & 140 \\
\hline BA & $12-30$ & 75 & 37 & 23 & 140 \\
\hline Bt1 & $30-90$ & 74 & 38 & 24 & 140 \\
\hline Bt2 & $90-145$ & 69 & 36 & 22 & 140 \\
\hline Bt3 & $145-200$ & 70 & 38 & 23 & 150 \\
\hline \multicolumn{6}{|c|}{ Profile 4: Agroforestry lower slope (ET_JIM-G-SLP2 } \\
\hline Ap & $0-10$ & 91 & 40 & 23 & 170 \\
\hline$A B$ & $10-30$ & 88 & 47 & 32 & 150 \\
\hline Bt1 & $30-60$ & 93 & 47 & 31 & 160 \\
\hline Bt2 & 60-105 & 93 & 48 & 31 & 170 \\
\hline Bt3 & 105-180 & 94 & 49 & 26 & 230 \\
\hline
\end{tabular}

Table 6 Mean values of physical and chemical characteristics of Nitisol $(0-20 \mathrm{~cm})$ as affected by slope class

\begin{tabular}{|c|c|c|c|c|}
\hline Soil properties & Upper slope (15-30\%) & Lower slope (2-5\%) & T value & Sign. \\
\hline Sand (\%) & 27 & 12 & 4.829 & 0.017 \\
\hline Silt (\%) & 22 & 25 & -0.441 & 0.689 \\
\hline Clay (\%) & 51 & 63 & -1.604 & 0.027 \\
\hline Bulk density $\left(\mathrm{g} \mathrm{cm}^{-3}\right)$ & 1.2 & 1.1 & 1.787 & 0.172 \\
\hline \multicolumn{5}{|l|}{ Particle size fractions (\%) } \\
\hline Coarse sand & 49 & 15 & 3.141 & 0.042 \\
\hline Medium sand & 34 & 33 & 0.097 & 0.929 \\
\hline Fine sand & 17 & 52 & -4.447 & 0.041 \\
\hline Coarse silt & 54 & 41 & 1.065 & 0.365 \\
\hline Medium silt & 32 & 21 & 1.392 & 0.258 \\
\hline Fine silt & 14 & 38 & -2.637 & 0.078 \\
\hline Water stable aggregates & 80 & 82 & -0.935 & 0.419 \\
\hline \multicolumn{5}{|c|}{ Water holding capacity w/w, \%) } \\
\hline FC (1/3 bar $)$ & 35 & 37 & -1.095 & 0.353 \\
\hline PWP (33 bar) & 23 & 24 & -0.662 & 0.555 \\
\hline AWC $\left(\mathrm{mm} \mathrm{m}^{-1}\right)$ & 120 & 127 & -1.567 & 0.215 \\
\hline
\end{tabular}

decomposition of organic matter and N-mineralization in the cereal system. Further, the land use system might be adversely affecting soil microorganisms which remains subject for future research. Slope effect of TN was also significant $(\mathrm{p}<0.05)$ with higher mean values in the lower slope $(0.22 \%)$ compared to $0.13 \%$ in the 
Table 7 Mean values of physical and chemical characteristics of Nitisols $(0-20 \mathrm{~cm})$ as affected by land use

\begin{tabular}{|c|c|c|c|c|}
\hline Soil property & Intensive cereal system & Agroforestry based system & T value & Sign. \\
\hline Sand (\%) & 28 & 15 & 3.677 & 0.032 \\
\hline Silt (\%) & 26 & 18 & -2.320 & 0.103 \\
\hline Clay (\%) & 46 & 67 & -5.536 & 0.012 \\
\hline Bulk density $\left(\mathrm{g} \mathrm{cm}^{-3}\right)$ & 1.2 & 1.1 & 1.163 & 0.329 \\
\hline \multicolumn{5}{|l|}{ Particle size fractions (\%) } \\
\hline Coarse sand & 43 & 19 & 6.453 & 0.008 \\
\hline Medium sand & 41 & 16 & 4.494 & 0.021 \\
\hline Fine sand & 30 & 39 & -3.307 & 0.045 \\
\hline Coarse silt & 59 & 30 & 7.769 & 0.004 \\
\hline Medium silt & 38 & 17 & 3.859 & 0.031 \\
\hline Fine silt & 21 & 42 & -3.23 & 0.045 \\
\hline Water stable aggregates & 79 & 87 & -3.068 & 0.055 \\
\hline \multicolumn{5}{|c|}{ Water holding capacity w/w, \%): } \\
\hline FC (1/3 bar $)$ & 35 & 37 & -1.424 & 0.250 \\
\hline PWP (33 bar) & 23 & 24 & -0.132 & 0.903 \\
\hline AWC $(\mathrm{mm} / \mathrm{m})$ & 112 & 135 & -9.000 & 0.003 \\
\hline
\end{tabular}

Table 8 Selected chemical characteristics of Nitisol profiles by land use type and slope

\begin{tabular}{|c|c|c|c|c|c|c|c|c|c|c|c|c|}
\hline \multirow[t]{2}{*}{ Horizon } & \multirow[t]{2}{*}{ Depth (cm) } & \multirow[t]{2}{*}{$\mathrm{PH} \mathrm{H}_{2} \mathrm{O}$} & \multirow[t]{2}{*}{ OC (\%) } & \multirow[t]{2}{*}{ TN (\%) } & \multirow[t]{2}{*}{$\mathrm{C} / \mathrm{N}$} & \multicolumn{7}{|c|}{ CEC and exchangeable bases $\left(\mathrm{cmol}^{(+)} \mathrm{kg}^{-1}\right)$} \\
\hline & & & & & & CEC & $\mathrm{Ca}$ & $\mathrm{Mg}$ & $\mathrm{Na}$ & $\mathrm{K}$ & TEB & PBS \\
\hline \multicolumn{13}{|c|}{ Profile 1: Intensive cereal upper slope (ET_ASAA-P002) } \\
\hline Ap & $0-20$ & 4.8 & 2.1 & 0.16 & 13 & 44 & 15 & 4 & 0.1 & 1.4 & 20 & 43 \\
\hline$A B$ & $20-40$ & 5.1 & 1.7 & 0.10 & 17 & 32 & 14 & 3 & 0.1 & 1.2 & 18 & 53 \\
\hline Bt1 & $40-80$ & 5.5 & 1.0 & 0.05 & 20 & 30 & 13 & 2 & 0.1 & 1.3 & 16 & 50 \\
\hline Bt2 & $80-200$ & 5.7 & 1.0 & 0.06 & 17 & 30 & 14 & 4 & 0.2 & 1.2 & 19 & 60 \\
\hline \multicolumn{13}{|c|}{ Profile 2: Intensive cereal lower slope (ET_AJJ-P001) } \\
\hline Ap & $0-20$ & 4.7 & 3.6 & 0.20 & 18 & 42 & 15 & 7 & 0.4 & 1.2 & 22 & 52 \\
\hline$A B$ & $20-42$ & 4.9 & 2.0 & 0.12 & 17 & 49 & 20 & 7 & 0.4 & 1.1 & 27 & 55 \\
\hline Bt1 & $42-90$ & 4.5 & 1.1 & 0.06 & 18 & 48 & 20 & 6 & 0.5 & 1.4 & 26 & 54 \\
\hline Bt2 & $90-200$ & 4.9 & 1.1 & 0.07 & 15 & 45 & 17 & 5 & 0.4 & 1.3 & 22 & 49 \\
\hline \multicolumn{13}{|c|}{ Profile 3: Agroforestry upper slope (ET_JIMLS-SP2) } \\
\hline $\mathrm{Ah}$ & $0-12$ & 6.2 & 2.5 & 0.25 & 10 & 37 & 13 & 14 & 0.2 & 2.2 & 29 & 78 \\
\hline BA & $12-30$ & 5.5 & 1.3 & 0.12 & 11 & 41 & 18 & 10 & 0.6 & 2.0 & 29 & 70 \\
\hline Bt1 & $30-90$ & 5.5 & 0.9 & 0.09 & 10 & 35 & 14 & 10 & 0.9 & 2.0 & 25 & 71 \\
\hline Bt2 & 90-145 & 5.3 & 0.6 & 0.06 & 10 & 32 & 14 & 8 & 0.2 & 2.1 & 23 & 72 \\
\hline $\mathrm{Bt} 3$ & $145-200$ & 5.8 & 0.4 & 0.04 & 10 & 30 & 12 & 11 & 0.2 & 2.0 & 18 & 77 \\
\hline \multicolumn{13}{|c|}{ Profile 4: Agroforestry lower slope (ET_JIM-G-SLP2) } \\
\hline Ap & $0-10$ & 5.5 & 3.6 & 0.33 & 11 & 30 & 11 & 8 & 0.2 & 3.0 & 21 & 70 \\
\hline$A B$ & $10-30$ & 5.9 & 1.9 & 0.13 & 14 & 28 & 13 & 8 & 0.1 & 2.0 & 22 & 79 \\
\hline Bt1 & $30-60$ & 5.6 & 1.5 & 0.13 & 12 & 27 & 12 & 9 & 0.1 & 2.2 & 22 & 81 \\
\hline Bt2 & $60-105$ & 5.6 & 1.1 & 0.10 & 11 & 30 & 12 & 10 & 0.1 & 2.4 & 23 & 77 \\
\hline $\mathrm{Bt} 3$ & $105-180$ & 5.5 & 0.4 & 0.03 & 12 & 30 & 14 & 8 & 0.1 & 2.2 & 23 & 76 \\
\hline
\end{tabular}

TEB total exchangeable bases, $P B S$ percent base saturation

upper slope (Table 11). Similar results are reported by Gebreselassie et al. (2015) who found increasing TN levels with decreasing slope.
The mean AP content, 10 and $8 \mathrm{mg} \mathrm{kg}-1$ for the cereal and agroforestry systems, were rated as low based on the ratings of Hazelton and Murphy (2007). Although 
Table 9 Available phosphorus and micronutrient contents $\left(\mathrm{mg} \mathrm{kg}^{-1}\right)$ of the surface horizons in the Nitisol profiles

\begin{tabular}{llllllc}
\hline Profile ID & Land use & Slope & AP & Fe & Mn & Zn \\
\hline ET_ASAA-P002 & Cereal & $15-30$ & 8 & 29 & 63 & 3 \\
ET_AJJI-P001 & Cereal & $2-5$ & 16 & 32 & 69 & 2 \\
ET_JIMLS-SP2 & Agroforestry & $15-30$ & 9 & 66 & 94 & 13 \\
ET_JIM-G-SLP2 & Agroforestry & $2-5$ & 8 & 60 & 98 & 10 \\
\hline
\end{tabular}

Table 10 Mean values of selected chemical characteristics of Nitisols $(0-20 \mathrm{~cm})$ as affected by land use

\begin{tabular}{|c|c|c|c|c|}
\hline Soil property & Intensive cereal system & Agroforestry based system & T value & Sign \\
\hline $\mathrm{pH}-\mathrm{H}_{2} \mathrm{O}$ & 5.29 & 6.12 & -6.935 & 0.006 \\
\hline OC (\%) & 2.00 & 2.12 & -0.620 & 0.579 \\
\hline Tot. N (\%) & 0.15 & 0.22 & -4.217 & 0.024 \\
\hline $\mathrm{C} / \mathrm{N}$ & 18 & 10 & 2.600 & 0.080 \\
\hline $\mathrm{AP}\left(\mathrm{mg} \mathrm{kg}^{-1}\right)$ & 10.0 & 8 & 0.504 & 0.649 \\
\hline \multicolumn{5}{|c|}{ CEC and basic cations $\left(\mathrm{cmol}(+) \mathrm{kg}^{-1}\right)$ : } \\
\hline CEC & 40 & 44 & 1.800 & 0.170 \\
\hline $\mathrm{Ca}$ & 14 & 16 & -1.507 & 0.229 \\
\hline $\mathrm{Mg}$ & 6 & 15 & -10.832 & 0.002 \\
\hline $\mathrm{Na}$ & 0.02 & 0.14 & 0.522 & 0.638 \\
\hline K & 1.60 & 3.0 & -3.705 & 0.024 \\
\hline PBS (\%) & 51 & 75 & -6.937 & 0.006 \\
\hline \multicolumn{5}{|c|}{ Micronutrients $\left(\mathrm{mg} \mathrm{kg}^{-1}\right)$ : } \\
\hline $\mathrm{Fe}$ & 37 & 97 & -8.895 & 0.003 \\
\hline $\mathrm{Mn}$ & 39 & 68 & -9.731 & 0.002 \\
\hline $\mathrm{Zn}$ & 3 & 13 & -8.278 & 0.004 \\
\hline $\mathrm{Cu}$ & 2 & 3 & -1.732 & 0.182 \\
\hline
\end{tabular}

Table 11 Mean values of selected chemical characteristics of Nitisols $(0-20 \mathrm{~cm})$ as affected by slope

\begin{tabular}{lllrl}
\hline Soil properties & $\begin{array}{l}\text { Upper slope } \\
(\mathbf{1 5 - 3 0 \% )}\end{array}$ & $\begin{array}{l}\text { Lower slope } \\
(\mathbf{2 - 5})\end{array}$ & T value & Sign. \\
\hline $\mathrm{pH}-\mathrm{H}_{2} \mathrm{O}$ & 5.85 & 5.67 & 0.835 & 0.465 \\
$\mathrm{OC}(\%)$ & 1.50 & 2.52 & -12.000 & 0.000 \\
Tot. $\mathrm{N}(\%)$ & 0.13 & 0.22 & -4.869 & 0.012 \\
$\mathrm{C} / \mathrm{N}$ & 8 & 15 & -25.000 & 0.000 \\
$\mathrm{AP}\left(\mathrm{mg} \mathrm{kg}^{-1}\right)$ & 10.0 & 17.0 & -5.085 & 0.015 \\
$\mathrm{CEC}$ and basic cations $\left(\mathrm{cmol}^{(+)} \mathrm{kg}^{-1}\right)$ & & & \\
$\mathrm{CEC}$ & 43.0 & 42.0 & 0.324 & 0.767 \\
$\mathrm{Ca}$ & 16.0 & 14.0 & 1.842 & 0.163 \\
$\mathrm{Mg}$ & 9.0 & 8.0 & 5.196 & 0.14 \\
$\mathrm{Na}$ & 0.04 & 0.06 & -0.16 & 0.923 \\
$\mathrm{~K}$ & 1.2 & 1.4 & -1.092 & 0.355 \\
$\mathrm{PBS}(\%)$ & 62.0 & 58.0 & 1.960 & 0.145 \\
$\mathrm{Micronutrients}\left(\mathrm{mg} \mathrm{kg}^{-1}\right):$ & & & \\
$\mathrm{Fe}$ & 61.0 & 68.0 & -0.733 & 0.516 \\
$\mathrm{Mn}$ & 46.0 & 55.0 & -1.741 & 0.180 \\
$\mathrm{Zn}$ & 9.0 & 9.0 & 1.000 & 0.391 \\
$\mathrm{Cu}$ & 3.0 & 2.0 & 0.775 & 0.95 \\
\hline
\end{tabular}

some profiles in the cereal system had high AP contents (Table 9), the mean values were not significantly different between the two land use types. The low levels of AP in spite of relatively higher doses DAP application (i.e., $150 \mathrm{~kg} \mathrm{ha}^{-1}$ ) in the cereal system suggests the unavailability of the applied phosphate in the soil solution. This was attributed to increased exchangeable acidity and higher P-sorption capacity of the strongly acidic soils under the cereal system. Literature indicates the applied phosphate is fixed by iron and aluminum compounds (i.e., sesquioxides) and hence, rendered unavailable in the soil solution in low pH soils (Schaetzl and Anderson 2005; Hillel 2004). On the other hand, AP contents were significantly $(\mathrm{p}<0.05)$ different between the two slope classes with higher mean values $\left(17 \mathrm{mg} \mathrm{kg}^{-1}\right)$ in the lower slope compared to $10 \mathrm{mg} \mathrm{kg}^{-1}$ in the upper. The conventional practice of farmers is to apply DAP at planting (i.e., basal application) when the monsoon rains are at their peak that results in the runoff removal of some of the applied fertilizer from the upper slopes that are deposited in the lower slopes.

On the other hand, the $\mathrm{CEC}$, exchangeable bases $\left(\mathrm{Ca}^{2+}\right.$, $\mathrm{Mg}^{2+}, \mathrm{K}^{+}$) and PBS of the soil were rated high based on the 
ratings of Landon (1991) while $\mathrm{Na}^{+}$appeared only in trace amount. The paired T-test showed no significant difference between land use type and slope classes except for $\mathrm{Mg}^{2+}$, $\mathrm{K}^{+}$and PBS. Mean values of $\mathrm{Mg}^{2+}\left(15 \mathrm{cmol}(+) \mathrm{kg}^{-1}\right), \mathrm{K}^{+}$ $\left(3 \mathrm{cmol}(+) \mathrm{kg}^{-1}\right)$ and PBS (75\%) in the agroforestry system were significantly higher than those in the cereal system (6 and $1.6 \mathrm{cmol}(+) \mathrm{kg}^{-1}$ of $\mathrm{Mg}^{2+}$ and $\mathrm{K}^{+}$and $51 \%$ PBS). The PBS was in the medium to high range (43-60\%) in the cereal system while it was high to very high (70-81\%) in the agroforestry system (Table 8 ). The generally high base saturation of the soil was consistent with high contents of exchangeable bases (chiefly $\mathrm{Ca}^{2+}$ and $\mathrm{Mg}^{2+}$ ) but not consistent with generally acidic soil reaction ( $\mathrm{pH}$ 5.5-6.2) that needs some explanation. First, the soils in the Ethiopian highlands have developed on recent Trapean lava flows that have high base status (Mohr 1971). Secondly, according to Buol et al. (2011) the volcanic parent materials such as rhyolites, granite, trachytes, ignimbrites, andesites and some acidic basalts that dominate the Ethiopian produce inherently acidic clays. Thirdly, the humid climatic conditions might have resulted in increased microbial oxidation to produced organic acids, which provide $\mathrm{H}^{+}$to the soil that can also contribute towards low soil pH (Schaetzl and Anderson 2005).

The mean values for $\mathrm{Fe}^{2+}, \mathrm{Mn}^{2+}, \mathrm{Zn}^{2+}$ and $\mathrm{Cu}^{2+}$ were respectively $37,39,3$ and $2 \mathrm{mg} \mathrm{kg}^{-1}$ in the cereal system while it was 97, 68, 13 and $3 \mathrm{mg} \mathrm{kg}^{-1}$ in the agroforestry system (Table 9). According to the ratings of Havlin et al. (1999), the micronutrient contents were rated as high to very high except for $\mathrm{Zn}^{+}$that was low to medium. The high levels of micronutrients is consistent with the low $\mathrm{pH}$ of the soil and the low $\mathrm{Zn}^{2+}$ contents are in agreement with previous report that indicated widespread $\mathrm{Zn}$ deficiency in the Nitisol areas of the Ethiopian highlands (Dibabe et al. 2007). According to FAO (2006b), low soil pH induces increase in micronutrient contents that may eventually lead to root toxicity unless soil $\mathrm{pH}$ is corrected through liming. The paired T-test showed significant $(\mathrm{p}<0.05)$ difference between land use types for $\mathrm{Fe}^{2+}, \mathrm{Mn}^{2+}$, and $\mathrm{Zn}^{2+}$ but slope effect was nonsignificant. The mean value of $\mathrm{Fe}^{2+}$ $\left(97 \mathrm{mg} \mathrm{kg}^{-1}\right), \mathrm{Mn}^{2+}\left(68 \mathrm{mg} \mathrm{kg}^{-1}\right)$ and $\mathrm{Zn}^{2+}\left(13 \mathrm{mg} \mathrm{kg}^{-1}\right)$ in the agroforestry system were significantly higher than 37 , 39 and $3 \mathrm{mg} \mathrm{kg}^{-1}$ of $\mathrm{Fe}^{2+}, \mathrm{Mn}^{2+}$ and $\mathrm{Zn}^{2+}$ in the cereal system (Table 10). According to Mohr (1971) and Davidson (1983), the soil parent materials in the agroforestry system are dominated by basic rocks such as alkali-olivine basalts, amphibole and mica that are rich in ferromanganese minerals thus explaining the exceptionally high $\mathrm{Fe}^{2+}$ and $\mathrm{Mn}^{2+}$ contents in these sites.

\section{Conclusion}

The study showed that land use practices and slope class significantly affects important soil physical and chemical characteristics. These include particle size distribution, plant available water contents (AWC), soil $\mathrm{pH}$ and $\mathrm{OC}$, TN, AP exchangeable basses and some micronutrients. The land use practices in the intensive cereal system was found to be adversely affecting important soil physical and chemical characteristics as compared to the agroforestry system. These include alteration of particle size distribution, strongly acidic soil reaction, organic matter depletion, multiple nutrient deficiencies $(\mathrm{N}, \mathrm{P}, \mathrm{K}$ and $\mathrm{Zn}$ ) and low plant available water content. Among the inappropriate land use practices include repeated cultivation to create fine seedbed that predisposes the soil to erosion, unbalanced fertilizer application, rotation of maize with potato that are depleting some nutrient stocks (e., K and $\mathrm{Zn}$ ), and removal of crop residues from fields. As can be seen from the significantly lower PBS in the cereal system, leaching of basic cations was intense that resulted in increased levels of exchangeable acidity. In addition, continued use of DAP and urea seems to have contributed to increased exchangeable acidity as well as accentuating the uptake and deficiency of other nutrients such as $\mathrm{K}$ and $\mathrm{Zn}$ that are not supplied in the fertilizer application. Slope position of the profiles also had significant effect on soil characteristics with significantly higher proportions of coarse textured particles that were low in OC, AP and TN contents in the upper slope compared to lower slopes. Organic matter and nutrient contents decreased with increasing slope gradient particularly in the cereal system indicating the effect of erosional losses of fine particles.

The data, therefore, provides useful information for planning soil management strategies that can address adverse effects of land use on soil characteristics. First and foremost, application of more balanced blend fertilizer that contains N, P, K and Zn combined with liming to raise the soil $\mathrm{pH}$ remains crucially important. In this connection, research needs to generate NPS and Zn-B blend fertilizer applications rates for different crops, soil types and land use systems. Increasing the rate of fertilizer application is particularly crucial in the agroforestry based system where current rates of fertilizer use are far too low. However, given the very high levels of $\mathrm{Zn}$ in the soil, $\mathrm{Zn}$-blend should not be extended to farmers in the agroforestry system. Secondly, organic matter management including restitution of crop residues and recycling of farm yard manure is fundamental in order to reverse the OC depletion and increase water holding capacity of the soil. Third, although Nitisols have high structural aggregate stability that are fairly resistant to erosion, their landform of occurrence (i.e., high to mountainous relief hills with steep slopes) makes the soils susceptible to degradation by water erosion. This calls for the implementation of integrated soil and water conservation measures that combine physical, 
biological and agronomic measures mainly in the cereal system. In addition, soil textural fractionation analysis indicates that repeated tillage practice is found to predispose the soil to erosion by adversely affecting the soil textural fractions. Therefore, minimum tillage combined with legume rotation (maize-tef-bean) observed in some parts of west Gojam (e.g., South Achefer and Bure) need to be widely disseminated among farmers in the cereallivestock highlands.

\begin{abstract}
Abbreviations
AP: available phosphorus ( $\mathrm{mg} \mathrm{kg}^{-1}$ ); AWC: available water content; BD: bulk density $\left(\mathrm{dgcm}^{3}\right) ; \mathrm{C} / \mathrm{N}$ : carbon to nitrogen ratio; $\mathrm{Ca} / \mathrm{Mg}$ : calcium to magnesium ratio; CEC: cation exchange capacity $\left(\mathrm{cmol}(+) \mathrm{kg}^{-1}\right)$; $\mathrm{Cu}$ : copper $\left(\mathrm{mg} \mathrm{kg}^{-1}\right)$; DAP: di-ammonium phosphate ( $\left.18 \% \mathrm{~N}, 46 \% \mathrm{P}_{2} \mathrm{O}_{5}\right)$; FC: field capacity; ITCZ: Inter Tropical Convergence Zone; $\mathrm{K}$ : Potassium $\left(\mathrm{cmol}(+) \mathrm{kg}^{-1}\right)$; Mg: Magnesium ( $\left.\mathrm{cmol}(+) \mathrm{kg}^{-1}\right)$; Mn: Manganese $\left(\mathrm{mg} \mathrm{kg}^{-1}\right)$; Na: Sodium $\left(\mathrm{cmol}(+) \mathrm{kg}^{-1}\right)$; PBS: percent base saturation; SC: sandy clay; TN: total nitrogen (\%); PWP: permanent wilting point; WSA: water stable aggregates; $\mathrm{Zn}$ : zinc $\left(\mathrm{mg} \mathrm{kg}^{-1}\right)$.
\end{abstract}

\section{Author's information}

The author is a Ph.D. working in the area of Soil Science and environment having 20 years of post-Ph.D. research, teaching and development work. Currently, he holds associate Professor's position with College of Natural and Computational Science of Addis Ababa University. Over the past years, he has been working on soil survey, characterization and mapping work with scientists from the Wageningen University and Research Centre and the International Soil Reference and Information Centre (ISRIC), the Netherlands. Some of his work has recently been published in a book entitled, "Soils of the Ethiopian Highlands: Geomorphology and Properties"—ISBN: 978-99944952-6-9. In addition, the author published a number of peer reviewed journal articles and book chapters previously.

\section{Acknowledgements}

The author acknowledges the technical support of CASCAPE field staff in the study sites. These technical assistance do not qualify for co-authorship since data accrual, analysis, interpretation and write was done solely by the author.

\section{Competing interests}

The authors declares that there is no financial or non-financial competing interests.

\section{Availability of data and materials}

I declare that the data and materials presented in this manuscript can be made publically available by Springer Open as per the editorial policy.

\section{Consent for publication}

The manuscript does not contain no data or information from any person or individual apart from his own field investigation. All data and information are generated and synthesized by the author himself.

\section{Ethics approval and consent to participate}

Not applicable to this manuscript submission.

\section{Funding}

This research was conducted as part of the action research and capacity building project entitled, "Capacity building for Scaling up of Evidence based best Practices for increased Agricultural Production in Ethiopia (CASCAPE)" with kind financial assistance from the Ministry of Foreign Affairs of the Dutch Government through its Embassy in Addis Ababa.

\section{Publisher's Note}

Springer Nature remains neutral with regard to jurisdictional claims in published maps and institutional affiliations.
Received: 13 January 2017 Accepted: 8 August 2017

Published online: 23 August 2017

\section{References}

Abrishamkesh S, Gorji M, Asadi H (2010) Long-term effects of land use on soil aggregate stability. Int Agrophys 25:103-108

Assen M, Amd Tegene B (2008) Characteristics and classification of the soils of the plateau of Siemen Mountains National Park. SINET Ethiopia J Sci 31(2):89-102

Baruah TC, Barthakur HP (1997) A textbook of soils analysis. Vikas Publishing House, New Delhi

Bouyoucos GJ (1962) Hydrometer method improvement for making particle size analysis of soils. Agronomy 5:179-186

Bremner JM, Mulvaney CS (1982) Total nitrogen. In: Page AL, Miller RH, Keeney DR (ed) Methods of soil analysis II. Chemical and microbiological properties. American Society of Agronomy, Soil Science Society of America

Buol SW, Southard RJ, Graham RC, McDaniel PA (2011). Soil genesis and classification, 6th edn. Wiley-Blackwell, London

Chimdi A, Gebrekidan H, Kibret K, Tadesse A (2012) Status of selected physicochemical properties of soils under different land use systems of Western Oromia, Ethiopia. J Biodivers Environ Sci 2(3):57-71

Davidson A (1983) The Omo river project: reconnaissance geology and geochemistry of parts of Ilubabor, Kafa, Gamo Gofa, and Sidamo. Ethiop Instit Geol Surv 2:1-89

Dibabe A, Bekele T, Assen Y (2007) The status of micronutrients in Nitisols, Vertisols, Cambisols and Fluvsisols in major maize, wheat, tef and citrus growing areas of Ethiopia. Ethiopian Agricultural Research Organization (EARO) Research Report, Addis Ababa

Elias E (2002) Farmers perceptions of soil fertility change and management. In: SOS-Sahel and institute for sustainable development, Addis Ababa

Elias E (2016) Soils of the Ethiopian highlands: geomorphology and properties. ALTERA Wageningen University Research Centre, The Netherlands. ISBN: 978-99944-952-6-9

Elias E, Morse S, Belshaw DG (1998) Nitrogen and phosphorus balances of Kindo Koisha farms in southern Ethiopia. Agric Ecosyst Environ 71(1):93-113

Eswaren $\mathrm{H}$ (1988) Taxonomy and management related properties of the red soils of Africa. In: Nyamapfene K, Hussein J, Asumadu K (eds) The red soils of eastern and southern Africa. Proceedings of an international symposium, Harare, pp 1-23

FAO (1984) Geomorphology and soils of Ethiopia. In: Assistance to land use planning and provisional soil association map of Ethiopia. Field document AG DP/ETH/78/003. Food and Agriculture Organization of the UN, Rome

FAO (1986) The Ethiopian highlands reclamation study (EHRS). vol 1, In: Main Report. Food and Agriculture Organization of the UN, Rome

FAO (2001) Lecture notes on the major soils of the world. In: ISRIC-ITC-Catholic University of Leuven World soil resources Report No 94. Food and Agriculture Organization, Rome

FAO (2006a) Guideline for soil description. 4th edn, Food and Agriculture Organization of the UN, Rome

FAO (2006b) Plant nutrition for food security: a guide for integrated nutrient management. In: FAO fertilizer and plant nutrition, vol 16. Food and Agriculture Organization of the UN, Rome

Gebrekidan H, Negassa W (2006) Impact of land use and management practices on chemical properties some soils of Bako area, western Ethiopia. Ethiop J Nat Res 8(2):177-197

Gebreselassie Y, Anemut F, Addis S (2015) The effects of land use types, management practices and slope classes on selected soil physico-chemical properties in Zikre watershed, North-Western Ethiopia. Environ Syst Res 4(3):1-7. doi:10.1186/s40068-015-0027-0

Haileslassie A, Priess J, Veldkamp E, Teketay D, Lesschen JP (2005) Assessment of soil nutrient depletion and its spatial variability on smallholders' mixed farming systems in Ethiopia using partial versus full nutrient balances. Agric Ecosyst Environ 108:1-16

Hailu H, Mamo T, Keskinen R, Karltun E, Gebrekidan H, Bekele T (2015) Soil fertility status and wheat nutrient content in Vertisol cropping systems of central highlands of Ethiopia. Agric Food Secur 4(19):1-10. doi:10.1186/ s40066-015-0038-0 
Havlin JL, Beaton JD, Tisdale SL, Nelson WL (1999) Soil fertility and fertilizers. Prentice Hall, New Jersey

Hazelton P and Murphy B (2007) Interpreting soil test results: what do all those numbers mean? CSIRO. Department of Natural Resources

Hillel D (2004) Introduction to environmental soil physics. Elsevier Academic Press, Amsterdam

IFPRI (2010) Fertilizer and soil fertility potentials in Ethiopia. In: Constraints and opportunities to enhance the system. International Food Policy Research Institute, Washington

Karltun E, Mamo T, Bekele T, Gameda S, an Kidanu S (2013) Towards improved fertilizer recommendations in Ethiopia—Nutrient indices for categorization of fertilizer blends from Ethiopia Soil Information System (EthioSIS) woreda soil inventory data. In: A discussion paper. The Ethiopian Agricultural Transformation Agency (ATA) and the Ministry of Agriculture, Addis Ababa

Laekemariam F, Kibret K, Mamo T, Karltun E, Gebrekidan H (2016) Physiographic characteristics of agricultural lands and farmers' soil fertility management practices in Wolaita zone, Southern Ethiopia. Environ Syst Res 5(24):1-15. doi:10.1186/s40068-016-0076-z

Landon JR (1991) Booker tropical soil manual: a hand book for soil survey agricultural land evaluation in the tropics and sub-tropics. In: Longman Scientific and Technical, Routledge

Mamo T, Hague I (1991) Phosphorus status of some Ethiopian soils. III, Evaluation of soil test methods for available phosphorus. Trop Agric 68:51-56

Mamo T, Christian R, Heiligtag Burkhard (2002) Phosphorus availability studies on ten Ethiopian Vertisols. J Agric Rural Dev Trop Subtrop 103(2):177-183
Mohr AP (1971) The geology of Ethiopia. Haile Selassie I University Press, Addis Ababa

Nelson DW and Sommers LE (1982) Total carbon, organic carbon and organic matter. In: Page AL (ed) Methods of soil analysis, Part 2: chemical and microbiological properties. Agronomy, Madison, pp 539-579

Olsen SR, Cole CV, Watanabe FS, Dean LA (1954) Estimation of available phosphorus in soils by the extraction with sodium bicarbonate. US Department of Agriculture, Washington

Schaetzl RJ, Anderson S (2005) Soils: genesis and geomorphology. Cambridge University Press, Cambridge

Smaling EM, Braun AR (1996) Soil fertility research in Sub-Saharan Africa": new dimensions, new challenges. Commun Soil Sci Plant Anal. 27(3-4):365-386

Stocking M (1988) Tropical red soils of Africa: Fertility management and degradation. In: Nyamapfene K, Hussein J, Asumadu K (eds) The red soils of eastern and southern Africa. Proceedings of an international symposium, Harare

Tan KH (1996) Soil sampling, preparation, and analysis. Marcel Dekker, New York

USDA-NRCS (2014) Soil survey field and laboratory methods manual. In: Soil Survey Investigations Report No. 51 Version 2. United State Department of Agriculture and Natural Resources Conservation Service, Lincoln

Van Reeuwijk LP (2006) Procedures for soil analysis, 6th edn. International soil reference and information centre (ISRIC), Wageningen, The Netherlands

Zewdie E (2013) Properties of major agricultural soils of Ethiopia. Lambert Academic Publishing, Germany

\section{Submit your manuscript to a SpringerOpen ${ }^{\odot}$ journal and benefit from:}

- Convenient online submission

- Rigorous peer review

- Open access: articles freely available online

- High visibility within the field

- Retaining the copyright to your article

Submit your next manuscript at $\boldsymbol{s p r i n g e r o p e n . c o m ~}$ 